\title{
Cartas e ficção, um capítulo da obra alencariana
}

\author{
[ Letters and fiction, a chapter of alencar's work
}

\section{Patrícia Regina Cavaleiro Pereira ${ }^{\mathrm{I}}$}

RESUMO - Lendo a correspondência de José Martiniano de Alencar (I829-I877), deparamonos com um conjunto de quase trezentas missivas de naturezas e finalidades distintas: cartas reais e fictícias. Tais textos epistolares passaram pelas mãos de muitos receptores - destinatários primordiais ou leitores secundários-, para quem o epistológrafo reservava diferentes formas de pronunciar-se, adequando o discurso aos objetivos almejados em cada carta. Com este artigo, pretendemos trazer uma reflexão a respeito da persona epistolar alencariana e pensar de que forma José de Alencar utilizou a habilidade de escritor de cartas também na construção de suas tramas romanescas. • PALAVRAS-CHAVE • Epistolografia; romantismo;
José de Alencar. • ABSTRACT - When we read the correspondence of José Martiniano de Alencar (I829-I877), we find almost three hundred letters of nature and distinct purposes: authentic letters from real life and fictional letters. Such epistolary texts passed through the hands of many receivers - primary or secondary readers - for whom the epistolographer reserved different ways to pronounce his discourse according to the objectives of each letter. With this article, we intend to bring a reflection about the alencariana epistolary persona and think about how José de Alencar used the ability of letter's writer also to build his romanesque plots. KEYWORDS · Epistolography; romanticism; José de Alencar.

Recebido em 6 de julho de 2015

Aprovado em 25 de julho de 2016

PEREIRA, Patrícia Regina Cavaleiro. Cartas e ficção, um capítulo da obra alencariana. Revista do Instituto de Estudos Brasileiros, Brasil, n. 64, p. 3I0-323, ago. 2016.

DOI: http://dx.doi.org/Io.II6o6/issn.23I6-90IX.voi64p3Io-323

I Universidade de São Paulo (USP, São Paulo, SP, Brasil). 


\section{PERSONA EPISTOLAR}

Quando jovem, José Martiniano de Alencar exerceu a advocacia e atuou na imprensa fluminense, mas foi pela literatura e política que enveredou de maneira intensa e definitiva. Escreveu artigos de teor jurídico e político, crônicas, romances-folhetins, peças de teatro e cartas, muitas e variadas cartas.

Ao lermos a correspondência alencariana, descobrimos dois "Alencares": o homem público - jornalista, escritor e político - que se utilizava largamente das missivas, privadas ou dadas a lume, como instrumento de trabalho; e o cearense reservado dos assuntos domésticos, que contrariava o "caráter nimiamente comunicativo do nortista e do brasileiro em geral”2 quando abordava a vida particular nas cartas trocadas com amigos ou parentes.

As cartas abertas foram suas aliadas em diferentes momentos da carreira literária e política. Entre junho e agosto de I856, como redator-chefe do Diário do Rio de Janeiro, Alencar marcou sua entrada no círculo literário fluminense ao redigir e publicar oito polêmicas Cartas sobre a Confederação dos Tamoios ${ }^{3}$. De I865 a I868, a divulgação das 26

2 MOTTA, Arthur. José de Alencar: o escritor e o político, sua vida e sua obra. Rio de Janeiro: F. Briguiet \& Cia., I92I, p. 58.

3 Poeta da Confederação dos Tamoios, Gonçalves de Magalhães (I8II-I882), que era então o mais célebre vate das letras pátrias, foi alvo de duras críticas do jovem José de Alencar. Segundo Antonio Candido, o autor de Suspiros poéticos e saudades "foi aclamado como fundador da literatura verdadeiramente nacional e reverenciado por um grupo de fervorosos seguidores”. Como era de esperar, a publicação das cartas provocou a manifestação dos "amigos do poeta", personalidades como Manuel José de Araújo Porto-Alegre (I806-I879), Frei Francisco de Monte Alverne (I784-I858) e o monarca Pedro II (I825-I89I). CANDIDO, Antonio. Iniciação à literatura brasileira, 5. ed. Rio de Janeiro: Ouro sobre Azul, 2007, p. 49. 
Cartas de Erasmo ${ }^{4}$ também foi marcante em sua trajetória, pois os textos favoreceram a inserção no universo político.

Em A comédia brasileira ${ }^{5}$, Como e por que escrevi Iracema ${ }^{6}$ e $O$ nosso cancioneiro 7 , cartas abertas que fizeram parte de seu projeto literário, o escritor difundia reflexões sobre a estética romântica e a instituição da literatura nacional. No cerne dessas missivas, publicadas, José de Alencar apresentou considerações que iam de aspectos relativos à prosa, poesia e dramaturgia brasileira a apontamentos relacionados à língua portuguesa empregada no Brasil.

Político controverso do Segundo Império, tido como um dos patriarcas da nossa literatura, o autor de $O$ guarani “ocupou o proscênio durante o espaço de uma geração e, apesar de ter morrido relativamente cedo, foi o primeiro escritor que se impôs à opinião pública como figura de eminência equivalente aos governantes, aos militares, aos poderosos"8.

Observamos, nesta breve explanação, que Alencar aplicou amplamente a técnica missivista na tentativa de consolidar seus projetos na vida pública. No entanto, além das cartas abertas, que ajudaram a traçar as trajetórias literária e política, ele também se valeu do talento de artífice da correspondência em sua ficção propriamente dita, na qual fez uso de outra face epistolar, como veremos a seguir.

\section{CARTAS E FiCÇão EM José de AlenCAR: O ROMANCE-FOlHETIM}

Portadoras de boas-novas ou de tribulações, as cartas estão entre os elementos narrativos presentes nas tramas alencarianas. Nelas, a missiva contribui, via de regra, para o rompimento e restabelecimento do fluxo narrativo, sendo também, na maioria das vezes, peça determinante na criação de afortunados desfechos para os enredos.

Analisando o tema, Antonio Candido 9 não nos deixa esquecer que os estudiosos da técnica epistolar aplicada à ficção "indicam, entre as suas características, a

\footnotetext{
4 As Cartas políticas de Erasmo ao Imperador e as Novas cartas políticas de Erasmo ao povo estão no quarto volume da Obra completa de José de Alencar. A reunião completa das missivas de Erasmo foi feita por José Murilo de Carvalho, em 2009. O historiador inseriu em sua organização as Novas cartas de Erasmo ao imperador, ausentes da obra completa e trazidas à luz por Tâmis Peixoto Parron em sua dissertação de mestrado: A política da escravidão no império do Brasil: 1826-I865 ou Cartas a favor da escravidão. PARRON, Tâmis Peixoto. A política da escravidão no Império do Brasil, I826-I865. Dissertação (Mestrado em História Social). Departamento de História da Faculdade de Filosofia, Letras e Ciências Humanas da Universidade de São Paulo, 2009; ALENCAR, José de. Cartas a favor da escravidão. Organização de Tâmis Parron. São Paulo: Hedra, 2008. (Série Escola da cidade).

5 Carta aberta publicada pelo jornal Correio Mercantil, em 7/II/I857, e em forma de folhetim, no Diário do Rio de Janeiro, em I4/II/I857.

6 Trata-se de duas cartas destinadas a Domingos José Nogueira Jaguaribe (I820-I890), primo de José de Alencar, publicadas em forma de prefácio e posfácio à primeira edição do romance Iracema (I865).

7 Conjunto de cinco missivas publicado no periódico O Globo em I874.

8 CANDIDO, Antonio. Iniciação à literatura brasileira, op. cit., p. 57.

9 Idem,. Recortes. São Paulo: Companhia das Letras, I993, p. 6I.
} 
proximidade maior com o leitor, que parece estar vendo a realidade se formar à medida que o missivista escreve". Fato que muito "ajudaria a verossimilhança”, já que nesses textos, o autor das cartas "é uma espécie de testemunha fidedigna da informação".

Era, portanto, com o intuito de intensificar o lado real das tramas que os escritores se utilizavam de alguns expedientes romanescos recorrentes, dentre eles, a introdução de missivas nos enredos. Item corriqueiro no cotidiano do século XIX, a carta é um tipo textual que documenta a história narrada, sua presença faz com que os fatos da ficção se aproximem da vida real dos leitores, que tanto apreciavam ver retratados os quadros do dia a dia no rodapé dos periódicos que circulavam pela imprensa ${ }^{\mathrm{TO}}$.

Se evocarmos mais uma vez as palavras do professor Candido"1 localizar alguns dos traços inerentes à constituição do público leitor e da estrutura narrativo-ficcional oitocentista. De acordo com ele,

[...] que mais atraiu o leitor daquele tempo em matéria de romance parece ter sido o de costumes, no qual ele encontrava a vida de todo o dia, sem prejuízo dos lances romanescos que eram então indispensáveis. O brasileiro parecia gostar de ver descritos os lugares, os hábitos, o tipo de gente cuja realidade podia aferir, e que por isso lhe davam a sensação alentadora de que o seu país podia ser promovido à esfera atraente da arte literária.

No caso alencariano, ainda é possível relacionar o artifício aplicado nos textos à técnica de escrita folhetinesca, com a qual Alencar e tantos outros escritores, seus contemporâneos, estavam familiarizados ${ }^{\mathrm{I2}}$. Marlise Meyer ${ }^{\mathrm{I3}}$, descrevendo o chamado "exagero amplificador" - uma das características dos romancesfolhetins por ela apontadas -, menciona a utilização da carta nos enredos. Para ela, a recorrente inclusão não apenas de missivas como também de outros tipos textuais - e menciona testamentos, depoimentos - provava o exacerbado uso de meios dos quais os escritores lançavam mão a fim de assegurar a verossimilhança e, consequentemente, conquistar o leitor, que se manteria fiel até o término da publicação.

Nascido na França, em I836, o romance-folhetim chega às terras brasileiras em

Io Marlise Meyer, refletindo a respeito do tema, afirma: "Ainda que não existam as necessárias pesquisas, de difícil execução dada a escassez de dados de tiragens e publicações, não faltam indícios da correlação entre a prosperidade do jornal e do folhetim”. MEYER, Marlise. Folhetim: uma história. São Paulo: Companhia das Letras, I996, p. 294 .

II CANDIDO, Antonio. O Romantismo no Brasil. São Paulo: Humanitas, 2002, p. 4I.

I2 Alencar publicou Cinco minutos (I856), O guarani (I857) e parte de A Viuvinha (I857) no rodapé do Diário do Rio de Janeiro antes de levá-los às casas de edição.

I3 MEYER, Marlise, op. cit., p.I6o. 
I83 $8^{\mathrm{I}}$. Mantendo as características apresentadas no Velho Mundo, os folhetins redigidos no Brasil eram também publicados durante semanas. Logo, como faziam os escritores europeus, com o intuito de garantir o interesse dos leitores pela trama, os brasileiros preocupavam-se especialmente em criar desfechos atrativos para cada um de seus folhetins ${ }^{\mathrm{IS}}$.

Partindo desse princípio, os autores dos textos aplicavam estratégias narrativas que se estenderiam, mais tarde, aos romances publicados pelas casas de edição. É o que afirma José Ramos Tinhorão:

[...] é do romance de folhetim que se originam as principais características da técnica do romance no Brasil: a constante intervenção do autor no desenrolar das histórias (inclusive dirigindo-se aos leitores em tom de conversa); a extrema complicação dos enredos, num desdobramento linear de quadros sem preocupação com a verossimilhança; a finalização de cada capítulo em clima de suspense; e a surpresa da retomada de personagens e situações anteriores em conexão inesperada com as ações atuais (chegaram a ser lugar-comum nas histórias românticas os casos de amor impossível, por descobrirem os amantes - sempre no último capítulo - que eram irmãos $)^{16}$.

Uma missiva instigante era, por conseguinte, um trunfo nas mãos do folhetinista. Ao adicionar uma carta à narrativa, o escritor aprimorava o cerzimento da estrutura textual e fazia com que os olhos de seu leitor permanecessem presos à história devido ao frescor e à inovação de rumos que o elemento epistolar trazia para a trama. Esse era um dos "macetes" garantidores da audiência de que nos fala Marlise Meyer ${ }^{17}$, novamente, na seguinte assertiva:

Comum a todos, e importantíssimo, era o suspense e o coração na mão, um lencinho não muito longe, o ritmo ágil de escrita que sustentasse uma leitura às vezes ainda soletrante, e a adequada utilização dos macetes diversos que amarrassem o público e garantissem sua fidelidade ao jornal, ao fascículo e, finalmente, o levasse ao livro.

A carta ficcional, como notamos, foi um dos recursos de que José de Alencar e outros folhetinistas-romancistas dispunham para aproximar ainda mais as narrativas do leitor. A presença das missivas fazia com que o público se envolvesse

I4 De 3 I de outubro a 27 de novembro desse mesmo ano, O capitão Paulo, de Alexandre Dumas, foi trazido a lume pelo Jornal do Comércio. A pesquisadora Marlise Meyer ressalta que entre "I839 e I842 os folhetins-romance são praticamente cotidianos no Jornal do Comércio, embora os autores ainda não sejam os mais modernos". Ibidem, p. 283

I5 Marlise Meyer nos recorda mais uma vez que "o romance-folhetim, fatiado nos jornais, retomado em volumes, novamente seccionado em fascículos, encanta a Europa que o engendrou e a América Latina que o acolheu como se fora coisa sua”. Ibidem, p. $4 \mathrm{I} 7$.

I6 TINHORÃO, José Ramos. Os romances em folhetins no Brasil: I830 à atualidade. São Paulo: Duas Cidades, I994, p. 28.

I7 MEYER, Marlise, op. cit., p. 303. 
com a trama, se emocionasse com a história e mantivesse o desejo de acompanhá-la até a apresentação do último folhetim. Eduardo Martins, ${ }^{18}$ que escreveu sobre o tema, assegura que o estilo epistolar "aproxima esses romances [Cinco minutos, O guarani e A Viuvinha] dos folhetins e funciona como índice de verossimilhança, articulando o enredo à vida do dia a dia”. Segundo ele, "[...] enquanto as crônicas adentravam os limites da fantasia, [...] o romance quer elidir o seu caráter de invenção arbitrária e apresentar-se como verdade, fruto, quer da experiência pessoal do narrador, quer das investigações, fossem elas realizadas em alfarrábios empoeirados ou entre os conhecidos da vizinhança”.

Nas próximas linhas, veremos, então, como se deu o emprego do elemento epistolar em duas narrativas-folhetins alencarianas.

\section{ROMANCES URBANOS \& MISSIVAS}

"Envio-lhe outro perfil de mulher, tirado ao vivo, como o primeiro"ıs, escreve José de Alencar na carta-prefácio que acompanha o romance Diva. Lembremos, pois, que os perfis de mulher aos quais se refere o escritor são narrativas cujas protagonistas, apesar de terem espírito romântico - na mais lírica e sentimental concepção da palavra -, são também voluntariosas e donas de temperamento forte ${ }^{20}$.

Antes, porém, de dar vida às suas mais populares personagens femininas, que protagonizam os perfis, Alencar dedicou-se à “criação" de outras mulheres, frágeis e menos caprichosas, figuras centrais de seus primeiros romances-folhetins historietas que, a priori, ajudaram-no a solucionar problemas financeiros ${ }^{2 \mathrm{I}}$.

Entre 22 e 29 de dezembro de I856, ele publica Cinco minutos no Diário do Rio de Janeiro; em $\mathrm{I}^{\circ}$ de janeiro do ano seguinte, leva $O$ guarani ao público do mesmo jornal; e, ainda em I857 - aos 2I de abril, lança $A$ Viuvinha ${ }^{22}$. Foi com essas primeiras narrativas que o "nosso pequeno Balzac"23 deu início efetivamente à sua produção literária.

Neste artigo, tendo em vista a influente presença epistolar na produção ficcional alencariana, procuramos fazer apontamentos referentes às duas primeiras narrativas do núcleo urbano da obra de José de Alencar. Escolhemos os folhetins Cinco minutos e A Viuvinha, pois, em ambos, a missiva é o alicerce estrutural - o que

I8 MARTINS, Eduardo Vieira. "José de Alencar: do folhetim ao romance em Cinco minutos". Biblioteca Brasliiana Guta e José Mindlin, 2016 (no prelo), p.I4.

I9 ALENCAR, José de. Obra completa. v. I. Rio de Janeiro: Editora José Aguilar, I960, p. 333.

20 Os romances que fazem parte dessa categoria são Lucíola (I862), Diva (I864) e Senhora (I875).

2I A fim de alavancar as vendas do periódico, o jovem cearense, então redator-chefe do Diário do Rio de Janeiro, decidiu elaborar breves tramas que seriam publicadas nos rodapés do jornal.

22 Devido a um equívoco cometido por Leonel de Alencar, irmão do escritor, A Viuvinha tem a sua publicação interrompida. José de Alencar narra os fatos em sua autobiografia literária Como e por que sou romancista ALENCAR, José de, op. cit., v. I, p.II5-Ir6.

23 CANDIDO, Antonio. Formação da literatura brasileira: momentos decisivos. II. ed. Rio de Janeiro: Ouro sobre Azul, 2007, p. 546. 
nos permite afirmar tratar-se de "cartas-romance" 24 - e, sobretudo, porque o elemento epistolar é peça-chave no decorrer de ambas as tramas.

Explicando melhor, levamos em conta que o protagonista de Cinco minutos narra "uma história, e não um romance"25 nas linhas de uma longa carta escrita à sua prima. Ao lermos essa missiva, deparamo-nos com o relato de um jovem que, devido a um atraso de cinco minutos, conheceu Carlota - a mulher por quem se apaixonou perdidamente. Em sua carta principal, destinada à senhora $\mathrm{D}^{* * *}$, há a introdução de missivas "secundárias", que norteiam os passos do missivista em meio aos percalços que surgiram no decorrer de sua história de amor.

Recuperemos o enredo. Depois do primeiro encontro, ocorrido fortuitamente em um ônibus, o jovem se esforçava por rever a moça, de quem não havia conseguido ouvir sequer o nome. Passam-se os dias e, não menos inesperadamente, ele a vê de relance durante a execução da Traviata em um dos teatros fluminenses. Após esse episódio, ainda sem conhecer nada a respeito de Carlota, o rapaz escreve à prima, sua correspondente:

Recolhendo-me no dia seguinte, achei em casa uma carta. Antes de abri-la conheci que era dela, porque lhe tinha imprimido esse suave perfume que a cercava como uma auréola.// Eis o que dizia: // Julga mal de mim, meu amigo; nenhuma mulher pode escarnecer de um nobre coração como o seu.// Se me oculto, se fujo, é porque há uma fatalidade que a isto me obriga. E só Deus sabe quanto me custa este sacrifício, porque o amo! // Mas não devo ser egoísta e trocar sua felicidade por um amor desgraçado.// Esqueça-me.// C”26.

Desiludido com as palavras da moça, ele decide fazer uma viagem à Tijuca. Lá, recebeu a segunda missiva de Carlota, o que lhe causou uma "surpresa misturada de alegria e de remorso" ${ }^{27}$. Nela, lemos os dizeres a seguir:

24 Lembremo-nos que os "romances Cinco Minutos, A Viuvinha, Lucíola e Diva são estruturados como extensas missivas [...]”. PEREIRA, Patrícia Regina Cavaleiro. “Há muito tempo que não te escrevo...”: reunião da correspondência alencariana (edição anotada). Dissertação (Mestrado em Letras). Faculdade de Filosofia, Letras e Ciências Humanas, Universidade de São Paulo - USP, São Paulo, 20I2. Disponível em: <http://www.teses. usp.br/teses/disponiveis/8/8I49/tde-3I0820I2-0958I/pt-br.php〉. Acesso em: 20 jun. 20I6, p.I2. Grosso modo, o romance epistolar consiste em uma narrativa construída por uma ou várias correspondências. Alguns exemplos representativos do gênero são: Os sofrimentos do jovem Werther (I774), de Goethe, As ligações perigosas (I782), de Chordelos de Laclos, e Drácula (I897), de Bram Stocker. Logo, não podemos afirmar que as duas narrativas mencionadas neste artigo pertençam a essa categoria, pois não há nelas uma troca efetiva de cartas, existe apenas a escolha do escritor por manter o texto epistolar como base da narrativa e a inserção pontual de missivas que muito contribuem para o andamento das tramas.

25 ALENCAR, José de, op. cit., v. I, p. I53.

26 Ibidem, p. I6o.

27 Ibidem, p. I6I. 
Meu amigo. Sinto-me com coragem de sacrificar o meu amor à sua felicidade: mas ao menos deixe-me o consolo de amá-lo. Há dois dias que espero debalde vê-lo passar, e acompanhá-lo de longe com um olhar! Não me queixo; não sabe nem deve saber em que ponto de seu caminho o som de seus passos faz palpitar um coração amigo. Parto hoje para Petrópolis, donde voltarei breve; não lhe peço que me acompanhe, porque devo ser-lhe sempre uma desconhecida, uma sombra escura que passou um dia pelos sonhos dourados de sua vida. Entretanto eu desejava vê-lo ainda uma vez, apertar a sua mão e dizer-lhe adeus para sempre. C..$^{28}$.

Assim que terminou a leitura da carta, o rapaz partiu ao encontro de sua amada, que já estava em Petrópolis, onde, finalmente, puderam trocar breves palavras. $\mathrm{O}$ diálogo estabelecido entre ambos, contudo, não foi suficiente para que acontecimentos inesperados deixassem de ocorrer. Na manhã do dia seguinte, o jovem deparou-se com uma "caixinha de pau-cetim" na qual encontrou uma sobrecarta endereçada a ele. Nela, havia o retrato de Carlota, "[...] alguns fios de cabelo e duas folhas de papel escritas por ela [...]" cuja leitura ele fez “[...] de surpresa em surpresa”29.

A missiva mencionada pelo narrador foi cuidadosamente inserida em dois capítulos/folhetins da narrativa, os de número VI e VII. Trata-se da mais longa carta de Carlota, na qual a moça expôs o sério problema de saúde que lhe acometia e o temor que sentia ao cogitar a possibilidade de iludir seu amado com falsas expectativas. Ainda assim, a jovem expressava o desejo de que ele fosse para a Itália, destino que lhe fora recomendado pelos médicos, em companhia dela e de sua mãe. Vejamos alguns trechos dessa extensa carta:

Devo-te uma explicação, meu amigo.// Esta explicação é a história da minha vida, breve história, da qual escreveste a mais bela página. [...]// Sim, meu amigo!... Estava condenada a morrer, estava atacada dessa moléstia fatal e traiçoeira, cujo dedo descarnado nos toca no meio dos prazeres e dos risos, nos arrasta ao leito, e do leito ao túmulo, depois de ter escarnecido da natureza, transfigurando as suas mais belas criações em múmias animadas. [...]// Sim, vem! Iremos pedir ao belo céu da Itália mais alguns dias de vida para nosso amor; iremos onde tu quiseres, ou onde nos levar a Providência ${ }^{30}$.

Depois de ler a mensagem, o rapaz inicia uma corrida desenfreada - passando por peripécias ${ }^{31}$ que bem caracterizam o gênero folhetinesco - a fim de chegar antes da partida do paquete. Malfadado o seu intento, a distância que a partir de então se interpôs entre os enamorados não impediu que Carlota continuasse a escrever-lhe; suas cartas permaneceram vivas na trama. A missiva seguinte, na qual a moça não

28 Ibidem, p. I6I.

29 Ibidem, p. I67.

30 Ibidem, p. I67-I7I.

3I Trata-se dos acontecimentos que ocorreram durante a viagem "louca, esvairada, delirante" que o jovem narrador empreendeu de Petrópolis ao porto de onde sairia o navio para a Europa, levando Carlota. Ibidem, p. I73. 
se despedia do narrador, aparece no capítulo X. Acompanhemos as palavras do narrador-missivista:

No meio da tristeza que me causara a sua ausência, o que me deu um grande consolo foi uma carta que ela me havia deixado, e que me foi entregue no dia seguinte ao da sua partida. // Bem vês, meu amigo, dizia-me ela, que Deus não quer aceitar o teu sacrifício. Apesar de todo o teu amor, apesar de tua alma, ele impediu a nossa união; poupou-te um sofrimento e a mim talvez um remorso. // Sei tudo quanto fizeste por minha causa, e adivinho o resto; parto triste por não te ver, mas bem feliz por sentir-me amada, como nenhuma mulher talvez o seja neste mundo ${ }^{32}$.

Assim que a lê, ele segue em direção à Europa, onde, "em todos os portos da escala do vapor havia uma carta que continha duas palavras apenas: 'Sei que tu me segues. Até logo"'33. No velho continente, os enamorados se reencontram e, durante a temporada de um ano que passam lá, a jovem se cura da grave moléstia. Em terras brasileiras, "como as andorinhas que voltam com a primavera", ${ }^{34}$ Carlota e seu amado vivem, enfim, dias de muita felicidade.

O narrador, ao término de sua missiva, ratifica a presença do gênero epistolar no relato despedindo-se de sua correspondente, $\mathrm{D}^{* * *}$, com as seguintes palavras: "Adeus, minha prima. Carlota impacienta-se porque há muitas horas que lhe escrevo; não quero que ela tenha ciúmes desta carta e que me prive de enviá-la. Minas, I2 de agosto"35.

Acabada a exposição do fio condutor da narrativa e das missivas que o tecem, reflitamos a respeito do emprego epistolar na trama. Notemos, primeiramente, que todas as missivas introduzidas na carta central são fruto da pena de Carlota. Não há uma troca de cartas efetiva, uma correspondência propriamente dita, a única missiva escrita pelo narrador é a enviada à prima, ou seja, a "carta-romance".

Se nos atentarmos, concluiremos que a personagem Carlota, apesar de não se enquadrar nos perfis de mulher alencarianos, exerce o importante papel de epistológrafa responsável pela condução da trama. Não seria demais afirmarmos também que os fatos da narrativa só se desenrolam em função de suas cartas, redigidas em tom dramático e de exagerado apelo sentimental - característica folhetinesca.

Recapitulando, sabemos que há, em Cinco minutos, quatro missivas fundamentais que direcionaram a narrativa. A primeira carta desencoraja o narrador a continuar nutrindo sentimentos em relação à amada desconhecida; a segunda missiva motivou a ida do rapaz a Petrópolis e, consequentemente, favoreceu o primeiro encontro voluntário dele com Carlota.

Nesse momento da trama, a disposição epistolar revela uma das estratégias folhetinescas aplicadas por Alencar. O quinto capítulo/folhetim termina quando o

32 Ibidem, p. I80.

33 Ibidem, p. I8I.

34 Ibidem, p. I83.

35 Ibidem, p. I84. 
narrador tem em mãos a longa e reveladora missiva de Carlota, cuja leitura se estende aos dois capítulos/folhetins seguintes, sexto e sétimo - manobra que evidencia o artifício de atração e manutenção do leitor.

Na terceira e mais longa carta do romance, a moça relata a razão que a afastava de seu amado e sugere que ele a acompanhe em uma viagem à Europa. Malogrado o projeto, a despeito dos esforços do rapaz, Carlota redige uma quarta e última missiva, que o motiva a persistir no propósito de revê-la; desenlace que, finalmente, se concretiza, colocando um ponto final na história.

Eis, com a apresentação dessas quatro cartas, a base epistolar que conduziu toda a narrativa. Lembramos que, ao escolher os dois primeiros romances urbanos da obra de José de Alencar como objeto de análise, não perdemos de vista que essas produções dotadas de ares folhetinescos - não apresentam a mesma dimensão literária de outros romances de sua obra, como Senhora ou Lucíola, para nos atermos à ficção urbana.

De acordo com Arthur Motta, "Cinco Minutos e A Viuvinha são dois ensaios poéticos de romances que esboçam a feição dominante dos perfis de mulher traçados pelo autor"36. O estratagema epistolar adotado pelo escritor foi o que nos interessou de perto quando fizemos a releitura dessas duas narrativas compostas dos mais genuínos preceitos românticos.

Dando continuidade às observações, discorreremos nas próximas linhas acerca da estrutura "carteadora" de A Viuvinha, mais um romance-missiva no qual as cartas funcionam como mecanismo que gera e soluciona problemas de maneira simples e irrefutável37.

"Mas eu não escrevo um romance, conto-lhe uma história [...]"38. Com essas palavras, o protagonista-missivista da trama - assim como fizera o narrador-epistológrafo de Cinco minutos -, descreve a carta-romance destinada à prima $D .^{* * *}$. Recordemos, brevemente, como se sucederam os fatos da narrativa.

Jorge é um bon-vivant que, ao decidir se casar com Carolina, sua noiva, descobre estar na miséria. Os negócios do pai, já falecido, tinham ido à bancarrota e existiam muitas dívidas a serem pagas devido aos gastos excessivos que o jovem tivera com a vida boêmia que levara.

Desesperado com a situação, o rapaz pensa, inicialmente, em desistir do casamento. Nessa passagem da narrativa, localizamos a primeira referência epistolar

36 MOTTA, Arthur, op. cit., p. I4I.

37 Em um de seus ensaios, José Ramos Tinhorão refere-se às decisões que os folhetinistas, em geral, tinham nas mãos no momento de definir os rumos de suas narrativas: “[...] levar seus personagens a insurgir-se contra o código oficial, passando eles, os romancistas, a enfrentar a acusação de imorais ou 'perigosos'; resolver o impasse pela tragédia e a morte; ou, habilmente, conciliar a problemática amoroso-social desencadeada pelos enredos através de imprevistos salvadores (a morte ou desmascaramento do opressor; o recebimento de uma herança etc.). Alternativas essas que, no fundo, valiam por uma forma de ceder às convenções salvando as aparências libertárias do Romantismo”. TINHORÃO, José Ramos, op. cit., p. I6. O aparecimento de uma carta, portanto, também desempenharia esse "papel romântico", pois solucionaria problemas intransponíveis de forma quase mágica.

38 ALENCAR, José de, op. cit., p. 2 II. 
da trama, a carta na qual ele explicaria para a mãe de sua noiva as razões que o tinham levado a tal tomada de atitude. Leiamos o trecho:

[Jorge] Sentou-se à mesa e começou a escrever com uma espécie de delírio uma carta à mãe de Carolina; mas, apenas havia traçado algumas linhas, a pena estacou sobre o papel. - Seria matá-la! Balbuciou ele ${ }^{39}$.

Abandonada a missiva, em meio a uma noite de agonia, o moço reflete e chega à conclusão de que a melhor maneira de fugir de seus compromissos seria a morte. Decidido a se matar, todavia, Jorge ainda se preocupava com a reputação de Carolina, com quem estava comprometido. Achou por bem levá-la, então, ao altar antes de cometer o suicídio.

É na noite de núpcias do casal que surge a segunda referência epistolar da trama: a carta suicida, apenas mencionada algumas vezes durante a narrativa $4^{40}$, que o rapaz havia redigido para sua esposa. Sobre ela, escreve o narrador-epistológrafo à prima:

[...] Não transcrevo aqui essa longa carta para não entristecê-la, $\mathrm{D}^{* * *}$, porque nunca li coisa que me cortasse tanto o coração. Jorge explicava à sua mulher a fatalidade que o obrigava, ele, votado à morte, a consumar esse casamento, que a devia fazer desgraçada, mas que ao menos a deixava pura e sem mácula ${ }^{4 \mathrm{I}}$.

Ao chegar nas Obras da Misericórdia, lugar também conhecido como "o templo do suicídio”, Jorge - que estava sendo vigiado de perto desde o início da trama pelo senhor Almeida, velho amigo de seu pai - desiste, afinal, da ideia de tirar a própria vida. Instruído pelo velho, no entanto, ele se aproveita do corpo de outro jovem que acabara de se matar e simula o próprio suicídio, comprovado em uma carta - peça-chave do plano elaborado por Almeida ${ }^{42}$. Acompanhemos a descrição do narrador:

Um dos guardas meteu a mão no bolso da sobrecasaca [que vestia o corpo do suicida], e achou uma carteira contendo algumas notas pequenas, e uma carta apenas dobrada, que ele abriu e leu: "Peço a quem achar o meu corpo o faça enterrar imediatamente, a fim de poupar à minha mulher e aos meus amigos esse horrível espetáculo. Para isso achará na minha carteira o dinheiro que possuo.

Jorge da Silva 5 de setembro de I844"43.

39 Ibidem, p.I96.

40 Uma dessas ocorrências se dá no capítulo XIV, quando o narrador relata à sua correspondente os fatos que se sucederam após a "morte" de Jorge: "Nisto a porta do quarto abriu-se, e Carolina, branca como a cambraia que a vestia, apareceu na porta, tendo na mão a carta de Jorge” (ALENCAR, vol. I, I960, p.2I9).

4I ALENCAR, José de, op. cit., p. 225.

42 Assim disse Almeida: “- Ali está o corpo de um infeliz; é um cadáver sem nome, sem sinais que digam o que ele foi; deite sobre ele uma carta, desapareça e daqui a uma hora o senhor terá deixado de existir”. Ibidem, p. 2I9.

43 Ibidem, p. 204-205. 
Por meio dessa carta forjada, portanto, Jorge declara-se morto para a sociedade e confirma seu desaparecimento para a mulher que havia acabado de desposar. Cinco anos se passam, afastado da vida social da corte, o falso suicida trabalha arduamente e salda suas dívidas, honrando o nome do pai. Enquanto isso, Carolina, que "não havia libado do amor senão perfumes", vivia com a mãe e era chamada por todos de "a Viuvinha"44.

Com a intenção de reaproximar-se de sua esposa, Jorge recorre, mais uma vez, às cartas. Agora, o que lemos, porém, não é uma missiva tradicional, mas "uma sobrecarta, fechada com este endereço: - A ela. [...] Não havia dentro nem carta, nem bilhete, nem uma frase, nem uma palavra; mas uma flor só, uma saudade”.45.

São essas missivas que fazem com que a viúva se aproxime novamente do "falecido" marido. Esses textos epistolares são os responsáveis pelo "renascimento" de Jorge. O narrador continua:

[...] porque todas as manhãs [a moça] achava a mesma carta sem palavras e a mesma flor. Quando isso tomou ares de uma perseguição amorosa, a moça revoltou-se, e deixou de tirar as cartas, que ficaram no mesmo lugar onde as tinham posto. Parecia que o autor dessa correspondência ou não se importava com a indiferença que lhe mostrava Carolina ou contava vencê-la à força de constância ${ }^{46}$.

Essa terceira missiva é reiterada pela quarta e última, que traz poucas, mas decisivas palavras, fazendo com que o casal se reencontre e tenha, assim como os enamorados de Cinco minutos, um final feliz: "Abrindo a carta, Carolina viu pela primeira vez algumas frases escritas, que seus olhos devoraram com avidez. Dizia: 'Amanhã à meia-noite no jardim. É a primeira ou a última prece de um imenso amor"'47.

Concluímos que, mais uma vez, a missiva é empregada na narrativa como item que provoca turbulências no decorrer da trama, mas que contribuiu de forma determinante para um desfecho venturoso. Em A Viuvinha, são também quatro as cartas decisivas, responsáveis pelo desenvolvimento do enredo, já que delimitam os eventos mais importantes da trama, sejam eles inquietantes ou alentadores: a "morte" de Jorge - e o consequente surgimento da imagem da "Viuvinha" - e o "renascimento" de Jorge.

Na narrativa de I857, acreditamos que há uma estrutura epistolar mais elaborada que a apresentada em Cinco minutos ${ }^{48}$. No primeiro romance-folhetim de Alencar,

\footnotetext{
44 Ibidem, p. 222.

45 Ibidem, p. 223.

46 Ibidem, p. 223.

47 Ibidem, p. 225.

48 Levantamos a hipótese de que o escritor pôde desenvolver um trabalho mais apurado em A Viuvinha, talvez, por não ter publicado a narrativa integralmente como romance-folhetim, situação inversa da ocorrida com Cinco minutos.
} 
as cartas - que provêm sempre da pena da mesma missivista - estão presentes na criação de uma série de eventos pitorescos e leves, idas e vindas do protagonista em busca de sua amada.

Tais fatos não trazem a mesma gravidade dos acontecimentos provenientes das missivas de A Viuvinha. Nesse romance, a ideia do suicídio estabelecida por meio de uma carta é a base de toda a primeira parte da trama, cuja continuação - o reencontro do casal - se dá, de novo, mediante textos epistolares.

Como afirmamos anteriormente, não nos esquecemos da simplicidade literária dessas duas primeiras publicações alencarianas. Temos consciência de que Cinco minutos e A Viuvinha estão entre os romances experimentais do escritor cearense; entretanto, os nossos olhos se voltaram para essas duas breves narrativas pelo interessante trabalho epistolar que o autor executa.

\section{POST-SCRIPTUM}

Como pudemos constatar, a criação epistolográfica de José de Alencar é vasta e merece uma investigação profunda e cuidadosa. Ambas as faces do epistolário do escritor, cartas privadas ou públicas, reais ou fictícias, fazem-nos refletir a respeito das funções da missiva dentro e fora do contexto literário.

As cartas provindas do epistolário verídico ou as missivas surgidas da pena ficcional alencariana ${ }^{49}$ ainda serão, certamente, tema de muitos artigos e trabalhos acadêmicos. Segundo Marcos Moraes ${ }^{50}$, "a carta/texto tanto pode ser 'material auxiliar', ajudando a compreender melhor a obra e a vida literária, quanto escrita que valoriza a função estética/poética; ou, ainda, 'texto literário' nas paragens do romance epistolar...”. É o que notamos também quando adentramos na produção epistolar desse jornalista, político e escritor, composta por uma ampla e variada gama de textos.

Considerando que Alencar optou pela missiva até mesmo quando decidiu elaborar sua autobiografia intelectual ${ }^{51}$, é possível apreendermos a grandiosidade de sua correspondência e de sua ficção "carteadora”. O legado epistolar alencariano, que vislumbramos aqui, continuará certamente sendo abordado em futuros artigos, nos quais as trajetórias política e literária de José de Alencar serão recontadas por meio de suas cartas.

49 Nora Bouvet, refletindo a respeito das facetas da produção epistolar, chama de 'cerradas', 'auténticas', 'verdaderas', 'históricas' o 'reales' a las cartas efectivamente enviadas a un destinatario determinado ('privadas') y 'abiertas', 'inventadas', 'fictícias', 'imaginadas' o 'apócrifas' a las cartas publicadas ('públicas'). En principio, se entiende por 'auténtica' o 'verdadera' la carta privada, es decir, dirigida y enviada efectivamente a un destinatario determinado, y por 'inventada' o 'ficcional' la que no cumpre esos requisitos". BOUVET, Nora Esperanza. La escritura epistolar. Buenos Aires: Eudeba, 2006, p. II4-II5.

50 MORAES, Marcos Antonio de. Sobrescrito. Teresa: revista de literatura brasileira/área de Literatura Brasileira. Departamento de Letras Clássicas e Vernáculas. Faculdade de Filosofia, Letras e Ciências Humanas. Universidade de São Paulo - n. 8/9. São Paulo: Editora 34, 2008, p. 9.

5 Trata-se de Como e por que sou romancista (I893). 
E em tal empreitada, haverá espaço, novamente, sem dúvida, para um estudo mais abrangente e extenso acerca da predileção do escritor pelas missivas na construção de sua obra ficcional, tema apenas introduzido neste artigo.

\section{SOBRE A AUTORA}

PATRÍCIA REGINA CAVALEIRO PEREIRA é mestre em Literatura Brasileira pela Universidade de São Paulo. Academicamente, trabalha com os seguintes temas: epistolografia e historiografia literária com ênfase no século XIX.

E-mail: prcpereira@hotmail.com

\section{REFERÊNCIAS BIBLIOGRÁFICAS}

ALENCAR, José de. Obra completa. v. I, III e IV. Rio de Janeiro: José Aguilar, I96o.

. Cartas a favor da escravidão. Organização de Tâmis Parron. São Paulo: Hedra, 2008. (Série Escola da cidade).

BOUVET, Nora Esperanza. La escritura epistolar. Buenos Aires: Eudeba, 2006.

CANDIDO, Antonio. Recortes. São Paulo: Companhia das Letras, I993. . O Romantismo no Brasil. São Paulo: Humanitas, 2002.

. Formação da literatura brasileira: momentos decisivos. II. ed. Rio de Janeiro: Ouro sobre Azul, 2007. . Iniciação à literatura brasileira. 5. ed. Rio de Janeiro: Ouro sobre Azul, 2007.

MARTINS, Eduardo Vieira. "José de Alencar: do folhetim ao romance em Cinco minutos". Biblioteca Brasiliana Guita e José Mindlin, 2016 (no prelo).

MEYER, Marlise. Folhetim: uma história. São Paulo: Companhia das Letras, I996.

MORAES, Marcos Antonio de. Sobrescrito. Teresa: revista de literatura brasileira/área de Literatura Brasileira. Departamento de Letras Clássicas e Vernáculas. Faculdade de Filosofia, Letras e Ciências Humanas. Universidade de São Paulo - n. 8/9. São Paulo: Editora 34, 2008.

MOTTA, Arthur. José de Alencar: o escritor e o político, sua vida e sua obra. Rio de Janeiro: F. Briguiet \& Cia., I92I.

PARRON, Tâmis Peixoto. A política da escravidão no Império do Brasil, I826-I865. Dissertação (Mestrado em História Social). Departamento de História da Faculdade de Filosofia, Letras e Ciências Humanas da Universidade de São Paulo, 2009.

PEREIRA, Patrícia Regina Cavaleiro. “Há muito tempo que não te escrevo...”: reunião da correspondência alencariana (edição anotada). Dissertação (Mestrado em Letras). Faculdade de Filosofia, Letras e Ciências Humanas, Universidade de São Paulo - USP, São Paulo, 20I2. Disponível em: <http://www. teses.usp.br/teses/disponiveis/8/8I49/tde-310820I2-0958I4/pt-br.php >. Acesso em: 20 jun. 2016.

TINHORÃO, José Ramos. Os romances em folhetins no Brasil: I830 à atualidade. São Paulo: Duas Cidades, I994. 